\title{
THE EFFECT OF GOOD CORPORATE GOVERNANCE, PROFITABILITY AND COMPANYSIZE ON SUSTAINABILITY REPORT DISCLOSURE
}

\author{
Putri Renalita Sutra Tanjung \\ Faculty Economics and Business, Universitas Mercu Buana
}

Article DOI: $\underline{\text { https://doi.org/10.36713/epra8161 }}$ DOI No: $10.36713 /$ epra8161

\begin{abstract}
This study aims to analyze the influence of Good Corporate Governance, Profitability, Good Corporate Governance, and Company Size on Sustainability Report Disclosure. The sampling technique used was purposive sampling. The research was conducted on the participating companies of the Indonesia Sustainability Report Award (ISRA) during the 20152019 period. The purpose of this study was to determine the effect of Good Corporate Governance, Profitability and Company Size on Sustainability Report Disclosure. The results of this study indicate that the profitability and size of the company have no effect on the Sustainability Report Disclosure. Good Corporate Governance has a significant effect on Sustainability Report Disclosure.
\end{abstract}

KEYWORDS: Profitability, Good Corporate Governance, Company Size, Sustainability Report, Indonesia Sustainability Report Award

\section{INTRODUCTION \\ Research Background}

In the era of globalization, the development of the business world is growing rapidly, which is marked by the emergence of various companies with various sectors. Companies are beginning to realize that doing business is not only done in terms of solely seeking profit from an economic perspective, but companies are also required to pay more attention to social and environmental responsibilities. To disclose a company report is not only based on a single bottom line, namely the company's financial condition but also on the triple bottom line, that is, apart from financial information, it also provides social and environmental information, which is then called a sustainability report (Eria Nissa, 2015).

Sustainability reports are reports carried out by companies as a company effort to become an accountable company for all stakeholders for the purpose of company performance towards sustainable development (Effendi, 2016: 212). The needs of the community, especially investors, for information on the extent to which the company has carried out social activities so as to make companies transparent about their social activities, so that sustainability reporting is not only a medium for disclosure but also as an evaluation and monitoring tool for public companies.

At the international level, there have been guidelines that become a joint reference for the preparation of sustainability reports, which have been prepared using the Global Reporting Initiative (GRI) guidelines (standards) and compiled separately from financial reports or annual reports, since 2005 many companies in Indonesia have made the GRI guidelines a standard. Sustainability Report. GRI is a company reporting guide to support sustainable development initiated by the United Nations through the Coalition for Environmental Economies (CERES) and UNEP in 1997. GRI is a non-profit organization that promotes social, economic and environmental sustainability. The GRI standards have developed from time to time, starting from the GRI Guidelines (GRI-G1) to the most recent GRI Global Sustainability Standard Board (GRI GSSB) introducing the GRI Standards which was launched in 2017 (Majalahncsr.id, 12 June 2017).

Sustainability reports are needed so that stakeholders, including the community, know all forms of corporate responsibility to society and the environment. This is due to the fact that many cases that occur in Indonesia are related to the environment, such as the case of environmental damage in the Mount Botak mining area, Maluku, which is used as gold processing land by PT PIP. It is suspected that the company uses hazardous and toxic materials such as cyanide and mercury in processing gold material which produces hazardous waste due to mining activities that cause environmental damage (www.kompas.com, 11 January 
In addition, there have been other environmental incidents of environmental pollution due to liquid waste from textile processing which has leaked to flow into sewers and seeps into groundwater as a result of PT Mahatex's activities in East Java. The residents asked the factory to stop factory operations and fix any negligence that occurred because according to Law No. 32 of 2009 and Law No. 74 of 2001 it was stated that everyone who carries out B3 (toxic waste) activities is obliged to prevent environmental pollution or damage from occurring (www.sindonews .com, 24 November 2018).

But this does not make all companies in Indonesia disclose sustainability reports, because they are stillvoluntary (temporary). Sustainability reports are now getting more and more attention from companies in the world and in Indonesia, it can be seen from the changes in guidelines and policies in the preparation of sustainability reports carried out by the Global Reporting Intinative. The change in guidelines is expected to make the company more transparent not only in financial aspects but also in environmental, social and governance aspects. The sustainability report shows a positive trend, until the end of 2016 there were 120 companies that had published sustainability reports in Indonesia. (www.beritasatu.com, 20 March 2018).

The company's concern for the environment can be seen from whether there is sustainability reporting or not. The NCSR (National Center for Sustainability Reporting) implementation annually holds the Indonesia Sustainability Reporting Award (ISRA). With this ISRA, it is hoped that it can increase corporate responsibility to stakeholders and increase company awareness of aspects of transparency and public accountability (Effendi, 2016: 214).

Sustainability reports are increasingly becoming a necessity for companies to inform about their economic, social and environmental performance as well as to all company stakeholders (Aryanti, 2016). The Sustainability Report contains not only financial performance information but also non-financial information consisting of information on social and environmental activities which emphasizes more on disclosure principles and standards that can reflect the level of activities of the company as a whole so that it allows the company to grow in a sustainable manner (sustainable performance).

Sustainability Report also requires companies to provide transparent information, an accountable organization through good corporate governance. The better the corporate governance, the more it forces the company to provide information about its social activities. Good Corporate Governance (corporate governance) is a set of policies that regulate the relationship between company management, shareholders, creditors, government, employees and internal and external stakeholders relating to their rights and obligations, or in other words Good Corporate Governance. As a system to direct and control the company so that it runs efficiently, transparently and consistently with respect to legislation. The implementation of Good Corporate Governance (GCG) is very much needed to fulfill the trust of the public and the international community as an absolute requirement for the industrial world to develop properly and healthily with the ultimate goal of realizing stakeholder value. Murwaningsari (2008) mentions five main principles contained in Good Corporate Governance (GCG), namely: transparency, accountability, responsibility, and independence.

The main idea of Good Corporate Governance (GCG) or good governance is to realize corporate social responsibility (CSR). Corporate Social Responsibility (CSR) encourages companies to be transparent about the details of their operations. It will reflect their commitment to be responsible and accountable for their practice. From a company perspective, this transparency enhances its reputation not only with its stakeholders and consumers, but also to key investors, and their employees. A company becomes more aware of its operational efficiency, and as such, can work towards improving its sustainability efforts and financial performance. In addition, sustainable disclosure can be a differentiator for potential stakeholders to invest in the company. Although sustainability reporting is not yet a mandatory requirement, the number of companies reporting on sustainability has grown steadily from 2011, 2013, 2015 and up to the present, as they recognize the value of taking this action.

Law Number 40 of 2007 concerning Limited Liability Companies (PT Law), which was passed on July 20, 2007. Article 74 of the Limited Liability Company Law states: (1) Companies that carry out their business activities in the field of and / or related to natural resources are obliged to implementing Social and Environmental Responsibility (TJSL)). (2) TJSL is the obligation of the Company which is budgeted and calculated as the cost of the Company, the implementation of which is carried out with due observance of appropriateness and fairness. (3) Companies that do not carry out their obligations are subject to sanctions in accordance with the provisions of laws and regulations (www.hukumonline.com).

With this, companies, especially limited liability companies engaged in and or related to natural resources, must carry out their social responsibility to the community. The discussion above explains that the community has a very high concern for the issue of social care carried out by the company. This can affect the profits that the company gets. Because if a company does not pay attention to the interests of the community 
and its environment, then the community will not give its support to the company. So whether or not the implementation of Corporate Social Responsibility (CSR) by the company can be measured by the profit earned by the company.

Profitability can be measured by several indicators such as: operating profit, net profit, return on investment and return on owner's equity. Profitability plays an important role in all aspects of business because it can show the efficiency of the company and reflect the company's performance. Profitability describes the ability of a business entity to generate profits by using all its capital. Increasing profits and maximizing the value of the company are interrelated in improving the welfare of its shareholders, so that these objectives are important in maintaining the survival of the company, improving the welfare of its workers, improving quality and product quality, because the higher the level of profitability of an entity. then the survival of the business entity will be more secure, the company's ability to generate profits and measure the level of operational efficiency and efficiency in using its assets. Investors who invest shares in a company certainly have the goal of getting a return, where the higher the company's ability to generate profits, the greater the return expected by investors, resulting in an increase in the company's value. The profitability ratio used in this study is ROE (Return On Equity). ROE is chosen to find out how much the return on investment the company has made by using all the equity owned by the company.

In addition to Good Corporate Governance and profitability, company size is also thought to be able toinfluence the disclosure of Corporate Social Responsibility in the Sustainability Report. company size is a scale where the size of the company can be classified (Nugraha, 2019). In general, large companies will disclose more information than small companies. Large companies are the entities most highlighted by the market. As a form of public accountability, companies will disclose more social information to stakeholders. Fahrizqi (2018) and Sembiring (2015) found a significant relationship between company size and CSR disclosure, while Anggraini (2006) found no evidence that the size of the company affects CSR disclosure.

Company size is a scale that serves to classify the size of an entity. In general, large companies will disclose social information or social responsibility more than small companies (Nugraha, 2019). This can be explained theoretically that large companies are business entities that cannot be separated from the risk of greater political pressure than small companies (Sudarmadji and Sularto (2007: 54). Political pressure is pressure for business entities that are widely highlighted by the wider community to express more social responsibility (CSR) for their business activities towards the surrounding environment. Whereas the existence of greater disclosure of social activities is a reduction in political costs for the company, so that the company in the long term can avoid enormous costs as a result of prosecution. Public. Sembiring (2005) states that large companies are issuers that are under the most focus, greater disclosure is a reduction in political costs as a form of corporate social responsibility. Cowen et al. (1987) in Purba (2019) states that the company isbigger than the community will have shareholders who may pay attention to the social programs made by the company and the annual report will disseminate information on social responsibility.

Several studies that have succeeded in proving a significant positive relationship between the variable company size and the extent of social responsibility disclosure have been carried out by Purwanto (2011) and Rahma (2010). But not all studies support the relationship between company size and the extent of corporate social responsibility disclosure. There are also studies that have failed to show a positive relationship between the two variables, namely research conducted by Oktariani (2014) and Mimba (2014). Based on the background description above, the authors are interested in conducting research with the title "The Effect of Good Corporate Governance, Profitability and Company Size on Sustainability Report Disclosure (Empirical Study of Participating Companies in the Indonesia Sustainability Report Award (ISRA) during the 2015 - 2019 Period)".

\section{Formulation of the problem}

Based on the background that has been described, the problem formulations in this study are:

1. Does Good Corporate Governance affect the disclosure of Sustainability Report?

2. Does Profitability affect the disclosure of Sustainability Report?

3. Does the size of the company (Size) affect the disclosure of the Sustainability Report?

\section{LITERATURE REVIEW}

\section{Stakeholder Theory}

Stakeholder theory is used as one of the main theories as the basis for sustainability report research. The first study that argues for stakeholders is strategic management: A Stakeholder Approach (Freeman, 1984). Stakeholder theory is a theory which states that a company is not an entity that only operates for its own interests, but must provide benefits to all its stakeholders (shareholders, creditors, consumers, suppliers, government, society, analysts, and other parties). This stakeholder group is taken into account by company management in disclosing whether or not the information in the company report is made (Ghozali 
The main purpose of stakeholder theory is to help managers understand their stakeholder environment and manage it more effectively among their existence. Companies with good implementation of Good Corporate Governance are thought to have a high probability of making voluntary disclosure of environmental social responsibility as an effort to fulfill stakeholder needs (Ulum, 2015: 31). In this case, the Company must also maintain relationships with stakeholders by accommodating existing wants and needs, therefore the survival of the organization depends on the support of stakeholders, this is done to fulfill the interests of all stakeholders.

Through the disclosure of sustainability reports (social and environmental disclosures), companies can provide more adequate and complete information related to activities and their effects on social and environmental conditions (Ghozali and Chariri, 2016).

\section{Sustainability Report}

According to Elkington (1997) a sustainability report is a report that contains not only financial performance reports but also non-financial information consisting of information on social and environmental activities that allow companies to grow sustainably. There are three aspects in the sustainability report, namely: 1 . economic performance $=$ profit, 2 . social performance $=$ people and 3 . environmental performance

= planet. Meanwhile, according to Effendi (2016: 212) Sustainability reporting is a report made by companiesto measure, disclose (disclose), as well as how the company's efforts to become a company that is accountable to all stakeholders for the purpose of company performance towards sustainable development. Companies must collect, control, and report to internal and external parties about the sustainability information they have in the sustainability report.

Sustainability Report is used as a means of communication where there is involvement between the company and stakeholders which is used to determine business decisions for both investors and management. By making a sustainability report the company gets a positive image and legitimacy from stakeholders (Effendi, 2016: 213).

\section{Disclosures in the Sustainability Report}

The Global Reporting Initiative (GRI) is a Sustainability report reporting guide that provides reportingprinciples, standard disclosures, and implementation guidelines for the preparation of sustainability reports by organizations, sector size or location. Disclosure of special standards in the sustainability report related to economic, environmental and social aspects (GRI Standards, 2016: 3), as follows:

a. Economic Standard Disclosures

The dimension of economic sustainability with the organization's impact on the economic situation for its stakeholders, and on the economic system at the local, national and global levels. Economic indicators describe the flow of capital among different stakeholders and the main economic impact of the organization across all levels of society. In the performance indicators, there are 13 components covering the following aspects: a. Economic Performance, b. Market Presence, c. Indirect Economic Impact, d. Procurement Practices, e. Anti Corruption, f. Anti-Competitive Behavior.

b. Environmental Standard Disclosures

The environmental dimension of sustainability relates to an organization's impact on living and non-living natural systems, including land, air, water and ecosystems. The Environment category includes impacts related to inputs (such as energy and water) and outputs (such as emissions, effluents and waste). This includes biodiversity, environmental compliance, and supplier environmental assessments. In the environmental standard indicator, there are 30 components covering the following aspects: a. Material, b. Energy, c. Water, d. Biodiversity, e. Emissions, f. Effluent and Waste, g. Environmental Compliance, h. Supplier Environmental Assessment.

c. Disclosure of Social Standards

The social sustainability dimension discusses the impact impacts related to products and services, which the organization has, the social systems in which the organization operates. There are 34 social standard indicators, covering the following aspects: a. Personnel, b. Labor / Management Relations, c. Occupational Health and Safety, d. Training and Education, e. Diversity and Equal Opportunity, f. Non Discrimination,

g. Freedom of association and collective protection, h. Child Labor, i. Forced or Compulsory Labor, j. Security Practices, k. Indigenous Peoples' Rights, 1. Human Rights Assessment, m. Local Community, n. Supplier Social Assessment, o. Public Policy, p. Customer Health and Safety, q. Marketing and Labeling, r.Customer Privacy, s. Socio-Economic Compliance. 


\section{Good Corporate Governance (GCG)}

Prior et.al (2008) defines corporate governance as "... a set of provisions that enable the stockholders by exercising voting power to compel those in operating control of the firm to respect their interests." support that encourages the company's operational control to be in line with and respect the interests of shareholders. Cadbury Committee in Murwaningsari (2008), states that corporate governance is a set of regulations that govern the relationship between shareholders, company managers, creditors, government, employees andother internal and external stakeholders relating to their rights and obligations or in other words. another is a system that regulates and controls the company.

\section{Return On Equity (ROE)}

According to Lubis, Sinaga, and Sasongko (2017) profitability is an important consideration for investors in investment decisions. High profitability indicates good company prospects so that investors will respond positively to these signals and the company value will increase. The company's profitability can be seen through several ratios such as Return On Assets (ROA), Return On Equity (ROE), and Return On Investment (ROI). In this research, the ratio used in measuring the value of the company is using Return On Equity (ROE).

\section{Company Size (Size)}

According to Brigham \& Houston (2011) company size is the size of a company that is shown or valued by total assets, total sales, total profits, tax expense and others. Company size is a big or small picture of a company which can be seen from the total assets it owns (Dewi and Sudiartha, 2017). Companies with a large scale in general will dare to issue more shares than small companies, with the aim of financing the needsfor operating growth that can increase the company's sales activities. With the increasing sales of the company, the profits will be high and can increase the value of the company.

\section{PAST RESEARCH}

As a reference basis in the preparation of this study, it is therefore very important to know the results of previous studies relating to the variables that have an influence on the disclosure of sustainability reports ina study.

Annisa Fauziah Afifulhaq (2018), conducted research entitled The Effect of Profitability, Leverage, Liquidity, Company Activities, and Corporate Governance on Sustainability Reporting Disclosures. The results of this study state that the variables of profitability and the board of directors have an effect on the disclosure of sustainability reporting, while the variables of leverage, liquidity, activity and the audit committee have no effect on disclosure of sustainability reporting.

Eria Nissa Awalia, Ratna Anggraini, and Rida Prihatni (2015), conducted research with the title of the influence of the board of directors, independent board of commissioners, leverage, and company activities on sustainability report disclosure. The results showed that the board of directors and leverage had no significant effect on the disclosure of the sustainability report. The independent board of commissioners had a negative and significant effect on the disclosure of sustainability reporting.

Umi Aniswatur Roudotul Jannah and Kurnia (2016) conducted a study entitled the effect of financial performance on the disclosure of sustainability reports. The results of this study indicate that profitability and liquidity have a positive effect on the disclosure of the sustainability report. Meanwhile, leverage and activity do not have a significant effect on the disclosure of the sustainability report.

Mariya Safitri and Saifudin (2019) conducted a study entitled Implications of Company Characteristics and Good Corporate Governance for the disclosure of sustainability reports. The results of this study state that the number of audit committee meetings and governance committee have a significant effect on the disclosure of sustainability reports. Meanwhile, profitability, liquidity, leverage, company activity, company size and the board of commissioners did not have a significant effect on the sustainability report disclosure.

Pujiastuti (2015) conducted a study entitled the influence of company characteristics and Good Corporate Governance on the extent of sustainability report disclosure. The results of this study state that company size, profitability, and board size in this study found a significant positive effect on the disclosure of the company's sustainability report, while leverage, listing age and level of share ownership by the public had a significant negative effect on the sustainability report. disclosure of corporate sustainability reports.

Dwita Aliniar Sri Wahyuni (2017), conducted a study entitled The Effect of Good Corporate Governance (GCG) Mechanisms and Company Size on the Quality of Sustainability Report Disclosure. The results of this study indicate that the board of commissioners, audit committee, concentrated share ownership, company size has no significant positive effect on the quality of the sustainability report disclosure. Meanwhile, the independent commissioner, institutional share ownership has a significant positive effect on the quality of the sustainability report disclosure.

Aulia Rayendra Rahman (2017), conducted a study entitled the effect of financial performance, 

state that profitability, liquidity and company age have a significant effect on the sustainability report disclosure, while liquidity and company size have no effect on the sustainability report disclosure.

Handre Diono \& Tri Jatmiko Prabowo (2017) conducted a study entitled Analysis of the Effect of Corporate Governance Mechanisms, Profitability, and Company Size on the Level of Sustainability Report Disclosure. The results of this study are (1) the variable size of the board of commissioners, composition of the independent commissioner board, composition of the female board of commissioners, profitability has a significant positive effect on the level of sustainability report disclosure and the variable size of the company has a significant negative effect on the level of sustainability report disclosure.

Latifah \& Tri Wahyu Oktavendi (2019), conducted research with the title Corporate Governance and Financial Performance on Sustainability Report. The results showed that the board of directors, audit committee and ROA had an effect on the sustainability report disclosure. Meanwhile, managerial share ownership and independent commissioners had no effect on the sustainability report disclosure.

\section{FRAMEWORK}

Based on the periodization chosen in this study and on the previous description, the theoreticalframework of this study is described as follows:

The Influence of Good Corporate Governance, Profitability and Firm Size on Sustainability Report Disclosure

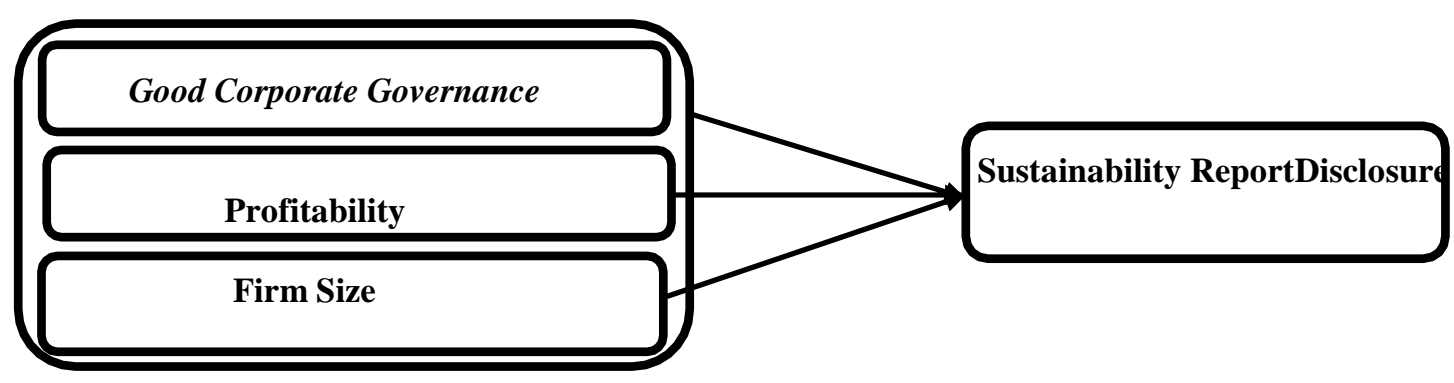

Figure 1. Framework

\section{RESEARCH HYPOTHESIS}

H1: Good Corporate Governance affects the Sustainability Report Disclosure

H2: Profitability affects the sustainability report

disclosure H3: Company Size Affects

Sustainability Report Disclosure.

\section{RESEARCH METHODS}

Research Variables and their Operations

1. Sustainability Report

The dependent or dependent variable is the variable that is affected or that is the result, because of the independent variable (Sugiyono, 2014: 4). The dependent variable used in this study is the sustainability report disclosure. According to the Global Reporting Initiative Standards (2016), Sustainability reports are a practice of measuring, disclosing, and accountability efforts of organizational performance in achieving sustainable development goals to internal and external stakeholders for organizational performance in achieving sustainable development goals. This dependent variable is measured through the Sustainability Report Disclosure Index (SRDI). SRDI assesses social and environmental responsibility according to the criteria according to GRI. SRDI calculation is done by giving a score of 1 if one item is disclosed and 0 if it is not disclosed. Furthermore, each item is added up entirely, then divided by the total number of disclosures based on GRI for the expected item. The formula for the Sustainability Report is as follows:

$\mathrm{SRD}=\quad \begin{gathered}\text { Number of items disclosed } \\ \text { Number of items expected }\end{gathered}$




\section{Good Corporate Governance}

Good Corporate Governance in this research is measured using the ASEAN CG Scorecard Country Reports and Assessments using the level 1 assessment category (179 items). This is because not all companies listed in the ASEAN CG Scorecard Country Reports and Assessments have applied a two-level assessment. The calculation of the assessment at each level is as follows:

a. Level 1

The assessment at level 1 contains five main aspects that refer to OECD principles and each aspect has 179 items that are used as guidelines. The five aspects are:

Table. 1. CG Scorecard Structure and Composition

\begin{tabular}{|l|c|c|c|}
\hline \multicolumn{1}{|c|}{ Level 1 } & $\begin{array}{c}\text { Number } \\
\text { of } \\
\text { Questions }\end{array}$ & $\begin{array}{c}\text { Weight (\% } \\
\text { of total } \\
\text { level 1 Score) }\end{array}$ & $\begin{array}{c}\text { Max. } \\
\text { Attainable } \\
\text { Score }\end{array}$ \\
\hline Part A : Rights of Shareholders & 25 & 10 & 10 Points \\
\hline Part B : Equitable Treatment of Shareholders & 17 & 15 & 15 Points \\
\hline Part C : Role of Stakeholders & 21 & 10 & 10 Points \\
\hline Part D : Disclosure and Tranparency & 41 & 25 & 25 Points \\
\hline Part E : Responsibilities of the Board & 75 & 40 & 40 Points \\
\hline
\end{tabular}

(Source : ASEAN CG Scorecard Assesment)

How to calculate the level 1 score is as follows:

$$
\begin{aligned}
& \text { Score }=\frac{\text { No. ofitemsScoredbyPLC }}{\text { Totalno. of Questions }} \times \text { Max. attainablescoreofpar(ponts) } \\
& \text { (Source : ASEAN CG Scorecard Assesment) }
\end{aligned}
$$

\section{Return on Equity}

Return On Equity is a ratio that shows how much equity contributes in creating net income. Investors will have more confidence in companies that can manage their capital properly which can benefit them. This variable is measured by calculating the results of the comparison between the amount of net income and the company's total equity which is formulated as follows:

\section{Firm Size}

$$
R O E=\frac{\text { Total Equity }}{\text { Tot }}
$$

The company as measured by total assets will be transformed in logarithmic form in order to equalize with other variables, because the total value of the company's assets is relatively large compared to other variables in this study. Size is formulated as follows:

$$
\text { SIZE }=\log (\text { total asset book value) }
$$

\section{RESEARCH POPULATION AND SAMPLE}

Population is a generalization area consisting of objects / subjects that have certain qualities and characteristics that are determined by researchers to study and then draw conclusions (Sugiyono, 2014: 16). The population in this study were companies participating in the Indonesia Sustainability Reporting Award $\neg$ for the period 2015-2019.

The sample is part of the number and characteristics of the population (Sugiyono, 2014: 62). The sample selection was carried out using purposive sampling method, namely the sampling technique with certain considerations selected based on criteria (Sugiyono, 2014: 68). The criteria used to select samples in thisstudy are:

1. Companies that have consistently participated in the Indonesia Sustainability Reporting Award (ISRA) during 2015-2019.

2. Companies that publish annual reports and sustainability reports consistently during 2015-2019.

\section{DATA ANALYSIS METHOD}

Data analysis was performed using the SPSS program, including the following review:

1. Descriptive Statistics Test

2. Classical Assumptions Test consisting of, Normality Test, Multicollinearity Test, Heteroscedasticity Test,and Autocorrelation Test 
3. The Feasibility Test Model consists of the Determination Coefficient Analysis (R2 test),

SimultaneousRegression Coefficient Test (F Test) and Partial Test (t-Test)

\section{DATA ANALYSIS RESULTS}

Data analysis was performed using SPSS 23. The analytical methods used in this study included analysis of descriptive statistics and multiple regression analysis.

\section{Descriptive Statistics}

Table 1. Descriptive Statistics

\begin{tabular}{|l|c|c|c|c|c|}
\hline & N & Minimum & Maximum & Mean & Std. Deviation \\
\hline SR & 50 &, 078 & 1,000 &, 35412 &, 236654 \\
GCG & 50 &, 167 &, 625 &, 36014 &, 109771 \\
ROE & 50 & -8.81 & 49.86 & 0.7149 & .95285 \\
SIZE & 50 & 30,398 & 34,438 & 31,99752 & 1,239935 \\
Valid N (listwise) & 50 & & & & \\
\hline
\end{tabular}

Source: Output SPSS 23

Based on the results of statistical tests Based on the results of descriptive statistical tests in the table with a sample size of 50 from 10 companies for 5 years in order to obtain the following data:

Disclosure of Sustainability Report (SR) has the lowest (minimum) value of 0.078 which is owned by PT Bank Negara Indonesia Tbk in 2017. In other words, the company discloses the least amount of sustainability reports by meeting economic, environmental and social aspects with Global guidelines. Reporting Initiative (GRI) Standard, namely 7.8\%. Meanwhile, the highest value (maximum) is 1,000 owned by PT. Pupuk Kalimantan Timur in 2017. This is due to PT Pupuk Kaltim planning, implementing, and monitoring the CSR program which refers to the CSR master plan based on Law No. 40 of 2007, as well as community empowerment programs through the Partnership and Community Development Program (PKBL) and Creating Shared Value (CSV), which aim to improve community welfare with a better quality of life. The average number (mean) of sustainability report disclosures in the companies of the 50 data studied was 0.35412 with a standard deviation of 0.236654 , which means that the standard deviation value is smaller than the average value (mean). It can be interpreted if the data distribution is evenly distributed, and shows the variations contained in the sustainability report disclosure index. This shows that the company's awareness in disclosing sustainability reports is quite low, and is still voluntary.

1. The GCG index has the lowest (minimum) value of 0.167 which is owned by PT Pertamina (Persero) Tbk in 2017. This shows that the amount of good corporate governance index disclosure data is only $16.7 \%$ of the total number of items in the industry and that year. Meanwhile, the highest (maximum) value of 0.625 was owned by PT Bank Negara Indonesia Tbk in 2015 and 2016. This shows that the number of members of the independent board of commissioners was $62.5 \%$ of the total number of commissioners in the industry and that year. The average (mean) number of independent commissioners in the company from the 50 data studied was 0.36014 with a standard deviation of 0.109771 , which means that the standard deviation value is smaller than the mean value. This shows the distribution of data evenly and can present the entire data.

2. Profitability has the lowest (minimum) value of -8.81 owned by PT Wijaya Karya (Persero) Tbk in 2015 . Meanwhile, the highest (maximum) value of 49.86 was owned by PT Indonesia Power in 2015. This is because this year there are the increase in sales is higher than the previous year. The average (mean) return on equity in the companies from the 50 data studied was 0.7149 with a standard deviation of

.95285, which means that the standard deviation value is smaller than the average value (mean). This shows the distribution of return on equity data evenly and can present the entire data.

3. Company size has the lowest (minimum) value of 30,398 owned by PT Wijaya Karya (Persero) Tbk in 2015. This is due to an increase in total assets by $26.4 \%$ to Rp. 15.9 trillion this was due to an increase in fixed assets by 63\%. Meanwhile, the highest value (maximum) was 34,438 owned by PT. Pertamina (Persero) Tbk in 2018. This is due to the number of total assets that have increased every year, coupled with the increase in Pertamina's assets in the Riau area with the completion of the transfer of oil sources inthe Rokan Block. The average (mean) size of the company from the 50 data studied was 31.99752 with a standard deviation of 1.239935, which means that the standard deviation value is smaller than the average value (mean). This shows that the distribution of company size variable data is evenly distributed and can present the entire data. 


\section{CLASSIC ASSUMPTION TEST}

The classic assumption test is carried out so that the regression model in the research is significant and representative. In the multiple regression analysis, it is necessary to avoid any standard assumption deviation so that problems do not arise in its use. The basic assumption is that the data is normally distributed; there is no heteroscedasticity, multicollinearity, and autocorrelation. Based on the normality test in this study, the Asymp value model. Sig. (2tailed) $=0.110$, then according to the provisions of $0.110>0.05$, the residual value is normal. Then the data in the model can be said to be normally distributed. Multicollinearity test which shows that the VIF value is below 10 , and the tolerance value is above 0.10 . From the results of these tests, it can be concluded that the regression model does not have multicollinearity problems. Heterokedatisitas test shows that there was no heteroscedasticity. This can be seen from the probability of its significance (Sig. Value) on each independent variable above the $5 \%$ confidence level or 0.05 . So it can be concluded that the regression capital does not contain heteroscedasticity. The autocorrelation test in this study used the autocorrelation test using the Durbin-Watson (DW) test. The results of the autocorrelation test data obtained no positive or negative autocorrelation, or it can be concluded that there is no autocorrelation.

\section{Hypothesis Testing Results}

\section{Determinant Coefficient Test Results $\left(\mathbf{R}^{2}\right)$}

According to Ghozali (2018: 97), the coefficient of determination essentially measures how far the model's ability to explain variations in the dependent variable. The ratio of determination aimed at $\mathrm{R}^{2}$ from the regression model is used to determine the dependent variable that can explain the magnitude of the variability of the dependent variable. The coefficient of determination is 0.218 or $21.8 \%$. This shows that the variation of sustainability report disclosure $21.8 \%$ is influenced by the ROE, GCG, and SIZE variables. Whileother factors outside the model influence the remaining $78.2 \%(100-21.8 \%)$.

\section{Model Feasibility Test Results (Test F)}

According to Ghozali (2018: 98), F statistical test is basically to show whether all independent variables are included.

Table 2.Simultaneous Significance Test Results (Test F) ANOVA $^{\mathrm{a}}$

\begin{tabular}{|c|c|c|c|c|c|c|}
\hline & Model & Sum of Squares & df & Mean Square & F & Sig. \\
\hline \multirow{2}{*}{1} & Regression &, 598 & 3 &, 199 & 4,268 &, $010^{b}$ \\
& Residual & 2,147 & 46 &, 047 & & \\
& Total & 2,744 & 49 & & & \\
\hline
\end{tabular}

a. Dependent Variable: SR

b. Predictors: (Constant), GCG,ROE,SIZE

Source: data processed with SPSS 23

Based on the table, it is known that the calculated $\mathrm{F}$ value of 4,268 with a probability of $0,000<0.05$; this indicates that the model used in this study is feasible. So in this regression model, it can be concluded that the variables of Good Corporate Governance, Profitability, and Firm Size affect Sustanaibility Report Disclosure.

\section{Significance Test Results for Individual Parameters (Statistical Test t)}

The statistical t-test shows how far the influence of one explanatory or independent variable individuallyin explaining the variation of the dependent variable. Tests carried out using a significance level of $0.05(5 \%)$. If the significance value is below 0.05 , simultaneously, the independent variable has a significant effect on thedependent variable (Ghozali, 2016: 97). T statistical test results are as follows: 


\section{Statistical Test Results $\mathbf{t}$}

Coefficients $^{\mathrm{a}}$

\begin{tabular}{|c|c|c|c|c|c|c|}
\hline & \multirow[t]{2}{*}{ Model } & \multicolumn{2}{|c|}{ Unstandardized Coefficients } & Standardized & \multirow[t]{2}{*}{$\mathrm{t}$} & \multirow[t]{2}{*}{ Sig. } \\
\hline & & $\mathrm{B}$ & Std. Error & Beta & & \\
\hline \multirow{4}{*}{1} & (Constant) & 2,129 & ,859 & & 2,479 & 017 \\
\hline & GCG & 659 & ,313 & ,306 & 2,108 & 041 \\
\hline & ROE & 004 & 019 &, 002 & 002 & ,999 \\
\hline & SIZE &,- 048 & ,028 &,- 252 & $-1,731$ & ,090 \\
\hline
\end{tabular}

a. Dependent Variable: SR

Source: dataprocessed with SPSS 23

Based on the table shows the testresults of multipleregression analysis as follows:

$$
\mathrm{SRD}=\text { 2,129 + 0,004 ROE + 0,659 GCG - 0,048 SIZE + e }
$$

Description of the regression coefficient:

a. A constant value of 2.129 states that if Profitability (ROE), Good Corporate Governance and Company Size (SIZE) are zero, then the amount of Sustainability Report Disclosure (SRD) is 2.129.

b. The regression coefficient for the Good Corporate Governance variable is 0.659 . The coefficient shows a positive sign, which means that every $1 \%$ increase in disclosure of Good Corporate Governance will increase the Sustainability Report Disclosure (SRD) by 0.659 . The test results for Good Corporate Governance have a t value of 2.108 with a significant level of 0.041 , which means that it is smaller than the probability value of 0.05 . This shows that the Good Corporate Governance variable has a significant effect on the disclosure of the sustainability report, so that hypothesis 1 (H1) is accepted.

c. The profitability variable regression coefficient (ROE) is 0.004 . The coefficient shows a positive sign which means that every addition of $1 \%$ Profitability (ROE) will increase the Sustainability Report Disclosure (SRD) by 0.004 . The test results on the Profitability variable (ROE) have a t value of 0.002 with a significant level of 0.999 , which means greater than the probability value of 0.05 . This shows that the Profitability variable (ROE) does not have a significant effect on the disclosure of the sustainability report, so that hypothesis $2(\mathrm{H} 2)$ is rejected.

d. The regression coefficient for the firm size variable (size) is negative at -0.048 . These results indicate that each additional company size (size) $1 \%$ will reduce the Sustainability Report Disclosure (SRD) by 0.048. The results of the firm size test (SIZE) have a t-calculated value of $-1,731$ with a significant level of 0.090 , which means that it is greater than the probability value of 0.05 . This shows that the firm size variable (SIZE) does not have a significant effect on the sustainability report disclosure, so hypothesis 3 (H3) is rejected.

\section{DISCUSSION}

\section{Effect of Profitability (ROE) on Sustainability Report Disclosure}

The results showed that profitability did not have a significant effect on sustainability reporting. This is not in accordance with the theory put forward by Ghozali and Chariri, 2007, that companies that have a high level of profitability tend to disclose more information, because they want to show the public and stakeholdersthat the company has a high level of profitability compared to other companies in the industry. the same one. So this difference can occur due to differences in the GRI standard items used, from previously using GRI G4 to GStandar. So that there are still not many companies that use this latest standard, resulting in the results of the research from the samples taken not showing a significant positive effect between profitability and disclosure of sustainability reports. This may also occur because of the company's awareness of the importance of disclosing SR so that companies with small levels of profitability have already disclosed their sustainability reports smoothly in the research year.

\section{The Effect of Good Corporate Governance on Sustainability Report Disclosures}

The practice and disclosure of sustainability reports is the implementation of the concept and mechanism of Good Corporate Governance (GCG) which has the principle that stakeholders need attention, both in terms of existing rules and establishing active cooperation for long-term survival between stakeholders. with the company. The supporting infrastructure for the practice and disclosure of sustainability reports is the governance structure and mechanism in the company. So that it can reduce information asymmetry, but if this information asymmetry occurs it can cause adverse selection and moral hazard, with 
the consequence of companies that do not practice and disclose sustainability reports. Based on the results of research conducted by Handre and Jatmiko (2017), it is stated that Good Corporate Governance affects the disclosure of sustainability reports.

\section{The Effect of Company Size on Sustainability Report Disclosure}

Based on the test results, it shows that the company size variable has no effect on the Sustainability Report disclosure. This shows that the greater the size of the company, it is not certain that the level of sustainability report disclosure will always be wider. This condition identifies that in order to gain legitimacy from stakeholders, large companies will not always disclose more sustainability reports in order to have an influence on internal and external parties who have an interest in the company. disclosure of social responsibility in the sustainability report is a social policy issue and its basis is voluntary. The decision to undertake a social responsibility and to disclose it is a management policy. So that the information disclosed by the company results in different levels of disclosure in accordance with management policies in each company. This study proves that an increase in the total assets of a company does not guarantee that the company will disclose its Sustainability Report. The results of this study are supported by previous research conducted by Saifudin and Mariya (2019), which states that company size has no effect on Sustainability Report disclosure and contradicts previous research conducted by Pujiastuti (2015) which states that company size affects the disclosure of sustainability reports.

\section{CONCLUSIONS AND RECOMMENDATIONS}

\section{Conclusions}

1. Good Corporate Governance has a significant effect on the disclosure of Sustainability Report in companies that participate in the Indonesia Sustainability Reporting Award, this shows that Good Corporate Governance is quite influential in pressuring management to disclose broader social information.

2. Retun on Equity has no effect on the disclosure of sustainability reports for companies that participate in the Indonesia Sustainability Reporting Award (ISRA), so companies that have high profitability will reflect that these companies also have sufficient available working capital, so companies will tend to disclose information only as needed. .

3. Company size has no effect on the disclosure of sustainability reports for companies that participate in the Indonesia Sustainability Reporting Award (ISRA), that an increase in the company's total assets does not guarantee the company to disclose its sustainability report.

\section{Recommendations}

Based on the results of the analysis of the discussions and conclusions that have been described. However, in this study there are still several limitations. Therefore, the researcher gives some suggestions for further researchers, it is expected to expand the object of research such as the manufacturing sector, mining, and others so that the object under study becomes more varied and can use or add other research variables that are thought to have an influence on disclosure of sustainability reporting. such as considering other projected Profitability Calculations with Quick Ratio, Cash Ratio or Leverage, and using the Corporate Governance mechanism with foreign ownership, managerial ownership, and others.

\section{REFERENCES}

1. Adhipradana, Fadhila dan Daljono. 2014. Pengaruh Kinerja Keuangan, Ukuran Perusahaan, dan Corporate Governanve Terhadap Pengungkapan Sustainability Report. Diponegoro Journal of Accounting. Vol 3, No. 1 . Jurusan Akuntansi, Fakultas Ekonomika, Universitas Diponegoro.

2. Aliniar, Dwita dan Sri Wahyuni. 2017. Pengaruh Mekanisme Good Corporate Governance (GCG) dan Ukuran Perusahaan Terhadap Kualitas Pengungkapan Sustainability Report. Kompartemen.Vol XV, No.1 Maret 2017. Universitas Muhammadiyah Purwokerto.

3. Amini, Imel Aisyah. 2019. Pengaruh Corporate Governance, Size, dan Profitabilitas terhadap Sustainability Report. Universitas Mercu Buana

4. Anggraini, Dewi. 2018. The Indonesia Sustainability Reporting Awards (ISRA) Announcement Influence On Abnormal Return and Stock Trade Volume (Empirical Study on ISRA Award-Winning Companies in2009-2016 Period). Archives of Business Research, 6(8), 61- 72.

5. Awalia, E. N., Anggraini, R., \& Prihatni, R. (2015). Pengaruh Dewan Direksi, Dewan Komisaris Independen, Leverage, Dan Aktivitas Perusahaan Terhadap Pengungkapan Sustainability Report. Jurnal Ilmiah Wahana Akuntansi, Volume10 No.2. Tahun 2015. Fahmi, Irham. 2014. Analisis Kinerja Keuangan.Bandung: ALFABETA, cv.

6. Bintara, R., Tanjung P. R. S. (2019). Analysis of Fundamental Factors on Stock Return, International Journal of Academic Research in Accounting, Finance and Management Sciences 9 (2): 49-64

7. Brigham, E. F., \& Houston, J. F. (2014), Dasar-dasar Manajemen Keuangan. Jakarta: Salemba Empat. Effendi, M. Arief. 2016. The Power of Good Corporate Governance Teori dan Implementasi.

8. Jakarta:Salemba Empat. 
9. Fauziyah, Annisa. 2018. Pengaruh Profitabilitas, Leverage, Likuiditas, Aktivitas Perusahaan, Dan Corporate Governance Terhadap Pengungkapan Sustainability Reporting. Universitas Muhammadiyah Surakarta.

10. GRI Standard. 2017. Global Reporting Initiative

11.Handre, D., \& Tri Jatmiko, P. 2017. Analisis Pengaruh Mekanisme Corporate Governance, Profitabilitas,Dan Ukuran Perusahaan Terhadap Tingkat Pengungkapan Sustainability Report. Diponegoro Journal Of Accounting, Vol. 6, No. 3. Tahun 2017. Semarang: Universitas Diponegoro.

12. Hidayah, Nurul (2015) Pengaruh Investment Opportunity Set (IOS) dan Kepemilikan Manajerial Terhadap Nilai Perusahaan pada Perusahaan Property dan Real Estat di Bursa Efek Indonesia. Jurnal Akuntansi/Volume XIX, No. 03, September 2015: 420-432

13.Idah. 2013. Corporate Governance dan Karakteristik Perusahaan dalam Pengungkapan Sustainability Report. Accounting Analysis Journal. Jurusan Akuntansi, Fakultas Ekonomi dan BIsnis, Universitas Negersi Semarang.

14.Ihyahul Ulum. 2015. Intellectual Capital Model Pengukuran, Framework Pengungkapan, dan Kinerja Organisasi. Malang:UMM Press

15.Imam Ghozali dan Anis Chairi. 2007. Teori Akuntansi. Semarang:Badan Penerbit Universitas Diponegoro Imam Ghozali. 2013. Aplikasi Analisis Multivariate Dengan Program IBM SPSS 21 Update PLS Regresi.

16.Edisi Tujuh. Semarang: Badan Penerbit Universitas Diponegoro.

17.Jannah, Umi Asniwatur Roudtul dan Kurnia. 2016. Pengaruh Kinerja Keuangan Terhadap Pengungkapan Sustainability Report Pada Perusahaan di BEI. Jurnal Ilmu dan Riset Akuntansi. Vol 5 No. 2. Surabaya: Sekolah Tinggi Ilmu Ekonomi Indonesia Surabaya.

18. Kasmir. 2016. Analisis Laporan Keuangan. Jakarta: Raja Grafindo Persada.

19. Latifah, \& Tri, W. O. 2019. Good Corporate Governance, Kinerja Keuangan Terhadap Sustainability Report. Jurnal Reviu Akuntansi dan Keuangan. Vol. 9 No.2, 200-213, Agustus 2019. Malang: Universitas Brawijaya

20.Mariya, S., \& Saifudin. 2019. Implikasi Karakteristik perusahaan dan Good Corporate Governance Terhadap Pengungkapan Sustainability Report. Jurnal Bingkai Ekonomi. Vol. 4, No. 1, Januari 2019. Semarang: Kampus Universitas Semarang

21.Muallifin, O. R., \& Priyadi, M. P. 2016. Dampak Pengungkapan Sustainability Report terhadap Kinerja Keuangan dan Kinerja Pasar. Jurnal Ilmu dan Riset Akuntansi, 5(5).

22. Muhammad, K., \& Aniktia, R. 2015. Pengaruh Mekaniseme Good Corporate Governance Dan Kinerja Keuangan Terhadap Pengungkapan Sustainability Report. Accounting Analys Journal, 4(3).

23. Nasir et al. 2014. Pengaruh Karakteristik Perusahaan dan Corporate Governance Terhadap Pengungkapan Sustainability Report Pada Perusahaan LQ45 Yang Terdaftar. Jurnal Ekonomi. Vol 22 No.1. Pekan Baru. Jurusan Akuntansi, Fakultas Ekonomi, Universitas Riau.

24.Pujiastuti, 2015. Pengaruh Karakteristik Perusahaan dan Good Corporate Governance Terhadap Luas Pengungkapan Sustainability Report. Jurnal Studi Manajemen dan Bisnis. Vol. 2, No.1. Yogyakarta: Universitas teknologi Yogyakarta.

25. Rahman, Aulia R. 2017. Pengaruh Kinerja Keuangan Dan Karakteristik Perusahaan Terhadap Pengungkapan

26. Sustainability Report. JOM Fekon Vol.4 No. 2 (Oktober) 2017. Universitas Riau.

27. Sari, Mega Putri Yustia dan Marsono. 2013. Pengaruh Kinerja Keuangan, Ukuran Perusahaan, dan Corporate Governance Terhadap Pengungkapan Sustainability Report. Diponegoro Journal of Accounting. Vol 2, No. 3.Semarang: Jurusan Akuntansi, Fakultas Ekonomika, Universitas Diponegoro.

28. Subramanyam, K.R. 2017. Analisis Laporan Keuangan. Jakarta: Salemba Empat.

29. Suryaningsih, Ayuk. 2017. Pengaruh Karakteristik Perusahaan dan Good Corporate Governance Terhadap Praktik Pengungkapan Sustainability Report. Jurusan Akuntansi, Fakultas Ekonomi dan Bisnis, Universitas Muhammadiyah Surakarta.

30.Tanjung, P.R.S., Wahyudi, S.M. (2019). Analysis the Effect Disclosure of Sustainability Report, Economic Value Added and Other Fundamental Factors of Companies on Company Value, International Journal of Academic

31.web.idx.id www.globalreporting.orgwww.kompasiana.com www.ojk.go.id 